\title{
Adaptasi Budaya oleh Warga Negara Asing di Indonesia
}

\author{
Frans Carlos Yosephin, Septia Winduwati \\ franscarlosjosephine@rocketmail.com,septiaw@fikom.untar.ac.id
}

Fakultas Ilmu Komunikasi Universitas Tarumanagara

\begin{abstract}
In communication, culture is one of the factors that influence the continuity of a relationship. The cultural background possessed by each individual is a considerable influence because there are various kinds of special characteristics of each region. The purpose of this study is to determine the cultural adaptation experienced by foreign citizens (WNA) living in Indonesia. The theoretical concept used in this research is interpersonal communication theory and intercultural communication. The research method used is qualitative research methods with in-depth interviews with three foreigners as informants. The results of the analysis show that foreigners as informants in the acculturation process state that informants from India find it easier to carry out the adaptation process in Indonesia compared to informants from New Zealand and the Netherlands, while in the assimilation process it is stated that those who adopt Indonesian cultural values are foreigners who come from from India while foreigners who come from New Zealand and the Netherlands only understand it, not to adopt the existing cultural values of Indonesia.
\end{abstract}

Keywords: communication, culture, cultural adaptation

\begin{abstract}
Abstrak
Di dalam komunikasi, budaya adalah salah satu faktor yang berpengaruh dalam kelangsungan suatu hubungan. Latar belakang budaya yang dimiliki individu merupakan pengaruh yang cukup besar karena terdapat berbagai macam ciri khusus dari setiap daerah. Tujuan penelitian ini untuk mengetahui adaptasi budaya oleh Warga Negara Asing (WNA) yang tinggal di Indonesia. Penelitian ini dikaji dengan teori komunikasi interpersonal dan komunikasi antarbudaya. Metode penelitian yang dipakai menggunakan metode penelitian kualitatif dengan metode wawancara mendalam dengan informan sebanyak tiga orang WNA. Hasil analisis menunjukkan bahwa informan yang berasal dari India lebih mudah dalam melaksanakan proses adaptasi di Indonesia dibandingkan dengan informan yang berasal dari New Zealand dan Belanda. Sedangkan proses asimilasi menyatakan bahwa adopsi nilai budaya Indonesia dilakukan oleh WNA yang berasal dari India sedangkan WNA asal New Zealand dan Belanda hanya memahaminya tanpa mengadopsi nilai budaya Indonesia.
\end{abstract}

Kata Kunci: adaptasi budaya, budaya, komunikasi

\section{Pendahuluan}

Komunikasi diartikan sebagai "penyampaian informasi" atau pesan dari komunikator kepada komunikan. Komunikator biasa disebut juga sebagai orang yang menyampaikan pesan atau sender sedangkan komunikan di sebut sebagai orang yang menerima pesan atau receiver. Tujuan dari proses komunikasi adalah untuk saling mengerti apa yang dibicarakan oleh komunikator dan komunikan. Menurut Harold D. Lasswell, komunikasi adalah Who Says What In Which Channel To Whom With What Effect? yang artinya adalah "Siapa mengatakan apa dengan saluran apa kepada siapa 
dengan efek bagaimana? Pengertian ini sering sekali kita dengar terutama di dunia komunikasi (Romli, 2017).

Komunikasi adalah proses pernyataan antar manusia, di mana yang dinyatakan itu adalah pikiran, perasaan seseorang kepada orang lain, dengan menggunakan bahasa sebagai alat penyalurnya. Komunikasi adalah mekanisme di mana relasi manusia ada dan berkembang melalui semua simbol pikiran, bersama dengan alat untuk menyalurkannya melalui ruang dan mempertahankannya sepajang waktu. Hal ini meliputi ekspresi wajah, sikap dan gesture, nada suara, kata-kata, tulisan, cetakan, jalan kereta api. Telegram, telepon dan apapun lainnya yang mungkin merupakan temuan terbaru dalam pengusaan ruang dan waktu. Ketika berkomunikasi, kita mencoba membagi bersama informasi, ide atau sikap. Sebab, komunikasi selalu memerlukan paling tidak 3 unsur, yakni: sumber, pesan dan tujuan (Rosmawaty, 2010:14-15).

Gudykunst dan Kim (Liliweri, dalam Soemantri, 2019) menyatakan sudah selayaknya terjadi interaksi di antara masyarkat sebagai mahluk sosial, namun kemampuan individu untuk berkomunikasi sesuai dengan norma-norma dan nilai-nilai budaya lokal tergantung pada proses penyesuaian diri atau adaptasi dari para pendatang. Saat seseorang menghadapi budaya baru maka diperlukan kemampuan khusus untuk mengatasi perbedaan budaya atau cultural gap di lingkungan baru, yaitu dengan adaptasi. Adaptasi budaya adalah suatu proses dimana seseorang belajar serta memahami peraturan-peraturan dan kebiasaan-kebiasaan budaya baru (Martin and Nakayama, 2010: 320).

Menurut Gamsriegler, komunikasi dengan gaya across culture terdiri dari dua konteks yaitu low contect culture dan high contect culture (Sudarmika, 2020). Low contect culture ini memberikan petunjuk dengan pesan yang verbal dan dengan gaya komunikasi yang secara langsung, secara to the point dan objektif. Sedangkan, menurut Edward T.Hall (dalam Liliweri, 2011) low context culture adalah suatu kondisi yang bermula dari individu dengan memiliki kode pesan yang lebih menuju terus terang yang mampu mempermudah khalayak untuk berbagi informasi dan pengalaman dari individu masing-masing. Sedangkan, budaya dengan konteks yang rendah mengartikan bahwa kebudayaan tersebut lebih kepada kepraktisan dan terus terang dari prosedur proses pesan informasi. Para pengikut budaya konteks rendah ini dengan tahap dari mengatakan apa yang mereka maksudkan dan menghendaki dari apa yang individu katakan.

Kemudian, konteks pada selanjutnya adalah high context culture. Konteks ini dapat tercapaui dengan cara bicara yang berisikan basa basi akan tetapi memiliki unsur yang implisit dan perilaku secara non verbal dalam penyampaian inti dalam suatu pesan informasi (Sudarmika, 2020). Menurut Edward T. Hall (dalam Liliweri, 2011), konteks ini bermula dari individu yang memiliki kode pesan yang implisit atau dengan petunjuk yang simbolis. Konteks ini dengan pengharapan kecil kepada individu dalam berbagi pesan informasi dan pengalaman.

Gudykunts dan Kim (Utami, 2016) berpendapat bahwa setiap orang memiliki motivasi yang unik atau berbeda-beda. Kemampuan dalam berkomunikasi apabila tidak asing bagi mereka seperti norma dan nilai yang baru bagi khalayak, tergantung pada masing-masing karena ada yang tidak bisa menyesuaikan dalam dirinya dan ada juga yang mampu beradaptasi dengan diri mereka. Walaupun sebenarnya, tujuan beradaptasi agar dapat menjadi manfaat dalam lingkungan baru.

Menurut Kim (Utami, 2016) terdapat dua tahap dalam adaptasi yaitu cultural adaptation dan cross cultural adaptation. Cultural adaptation mengartikan bahwa 
proses awal mula komunikasi dimulai dari komunikator atau seseorang yang menyampaikan pesan, medium dan penerima pesan, dan pada akhirnya akan menimbulkan terjadinya proses encoding dan decoding. Pada tahap ini dapat diartikan bahwa terjadinya peningkatan dalam perubahan pada saat audiens berpindah dalam lingkungan barunya.

Tahap yang kedua adalah cross-cultural adaptation, di mana terdapat 2 hal yaitu Pertama, acculturation yang berarti bahwa terjadinya proses ini pada saat tamu asing atau orang asing telah menghadapi proses komunikasi atau sosial dengan kebudayaan baru atau asing bagi individu. Seiring dengan berjalannya waktu, tamu asing atau individu asing tersebut secara perlahan akan memahami kebudayaan baru tersebut. Faktanya, budaya lama sudah memberikan pengaruh dalam proses adaptasi individu, hal tersebut dapat dinamakan sebagai deculturation. Kemudian, terdapat juga dalam perubahan akulturasi, dimana perubahan ini membawa pengaruh pada individu asing yang memasuki dunia kebudayaan baru. Pengaruh yang terjadi seperti psikologis maupun perilaku sosial individu. Hal tersebut menimbulkan terjadinya resistensi pada kebudayaan baru, sehingga bukan berarti tidak mungkin individu asing atau individu yang memasuki kebudayaan baru tersebut mengisolasi diri dari penduduk lokal (Utami, 2016).

Menurut Gudykunts dan Kim, hal kedua menjadi bagian tahap yang sempurna dari kata adaptasi, yaitu assimilation yang berarti situasi yang muncul dimana individu asing atau memasuki dalam kebudayaan baru berusaha untuk meminimalisir penggunaan budaya lama dengan tujuan agar terlihat seperti penduduk lokal. Asimilasi dapat terjadi setelah munculnya perubahan akulturasi. Namun kenyataannya, proses asimilasi ini tidak tercapai pada titik yang sempurna. Kim, juga mendefinisikan bahwa proses adaptasi antar budaya berarti proses yang saling berhubungan maupun saling berpengaruh satu sama lain dapat melalui kegiatan dari komunikasi individu asing dengan lingkungan sosial dengan karakteristik kebudayaan baru yang didatanginya. Proses adaptasi ini terbayang pada adanya kesesuaian diantara bentuknya komunikasi dari individu asing yang memasuki kebudayaan baru dengan bentuk komunikasi yang telah disetujui oleh khalayak dan kebudayaan lokal atau setempat. Begitu juga dengan sebaliknya, kesesuaian bentuk komunikasi dapat menopang terjadinya adaptasi antarbudaya.

Berdasarkan penjelasan di atas, penulis meneliti adaptasi budaya pada Warga Negara Asing yang tinggal di Indonesia.

\section{Metode Penelitian}

Dalam penelitian ini, penulis menggunakan pendekatan kualitatif. Subjek dalam penelitian ini ditentukan dengan kriteria yakni informan yang masih menjadi Warga Negara Asing (WNA) walaupun sudah tinggal di Indonesia. Terdapat tiga informan yang berasal dari India, New Zealand dan Belanda yang bekerja dan tinggal di Indonesia dalam waktu lama sehingga sudah mengalami proses adaptasi budaya. Objek dalam penelitian ini adalah proses adaptasi budaya oleh (WNA yang tinggal di Indonesia.

Teknik pengumpulan data dalam penelitian ini dengan menggunakan teknik wawancara di mana penulis melakukan wawancara secara langsung dan memperdalam lagi dalam hal bertanya sehingga dapat tercapai jawaban yang luas mengenai topik penelitian ini. Wawancara yang digunakan dalam penelitian ini adalah dengan in-depth interview dengan tujuan lebih memperdalam suatu informasi sehingga mampu 
memperoleh informasi yang sesuai harapan mengenai makna subjektif, pemikiran, perasaan, sikap, perilaku dan sebagainya.

\section{Hasil Temuan dan Diskusi}

Berdasarkan hasil wawancara dengan ketiga informan, didapati bahwa proses adaptasi budaya masing-masing WNA cenderung sama. Dalam konteks komunikasi interpersonal yang dialami oleh ketiga informan yang berlatar belakang budaya berbeda-beda, proses adaptasi dimulai dengan komunikasi tatap muka dengan warga lokal.

Dalam proses adaptasi budaya yang dilalui oleh ketiga informan meliputi tiga unsur yaitu sumber, pesan, dan tujuan (Rosmawaty, 2010). Sumbernya adalah WNA atau WNI. Pesannya adalah pesan komunikasi yang dibangun. Tujuannya adalah mendapatkan hubungan baik dengan teman kerjanya.

Informan yang berasal dari Belanda berinisial RJ memahami bahwa pesan yang disampaikan oleh orang Indonesia ketika ia berinteraksi selama ini cenderung berbelitbelit. Terdapat maksud lain yang butuh dipahami dalam konteks komunikasi dalam interaksi itu.

Seperti dalam teori komunikasi antarbudaya, terdapat dua konteks budaya yaitu low context culture dan high context culture. Low context culture merupakan gaya komunikasi to the point seperti warga negara Belanda. Sedangkan high context culture yakni komunikasi yang cenderung berbelit-belit seperti orang Indonesia.

Dalam penelitian ini, akulturasi dari ketiga informan berbeda-beda. Informan yang berinisial VM, warga negara India, mengatakan bahwa ia sudah memahami nilai budaya yang ada di Indonesia yaitu menggunakan kata panggilan mas atau mbak ketika seseorang tidak mengetahui nama orang lain yang disapa. VM sudah memahami budaya ini karena nilai budaya ini ada juga di India sehingga tidak sulit bagi VM mempraktikkannya. Sedangkan informan yang berinisial PW, warga negara New Zealand, mengatakan bahwa ia membutuhkan waktu untuk beradaptasi dengan kata panggilan yang merupakan nilai budaya yang ada di Indonesia. PW sudah tinggal 18 tahun di Indonesia sehingga sekarang ia sudah terbiasa mempraktikkannya.

Informan RJ, warga negara Belanda, mengatakan bahwa ia mengalami kesulitan akan penggunaan kata sapaan orang pada awal ia tiba di Indonesia. Namun setelah tiga bulan tinggal di Indonesia, RJ sudah mulai terbiasa dan paham dengan penggunaan kata sapaan mas dan mbak. Dalam temuan ini, asimilasi dari ketiga informan berbeda-beda. Pertama, informan VM, asal India, menjalani proses asimilasi sesuai dengan teori karena VM melakukan hal yang sama mengenai kemandirian. Ia memahami dan menerima nilai-nilai budaya dalam hal ini adalah gaya hidup.

Kedua, informan PW, warga New Zealand, proses asimilasi yang dialami tidak berjalan sesuai dengan teori karena PW memahami penggunaan bahasa tetapi tetap menggunakan bahasa negara asalnya. Selain penggunaan bahasa, PW memahami bahwa kebudayaan orang Indonesia terlalu religius tetapi tidak menunjukkan bahwa ia juga religius.

Ketiga, informan RJ, warga negara Belanda, proses asimilasi yang dialami tidak berjalan sesuai dengan teori karena RJ tidak langsung menyesuaikan diri dan masih menggunakan kebudayaan lama yaitu low context culture dan masih merasa risih dengan kebudayaan Indonesia yang berkomunikasi secara berbelit-belit. Kebudayaan Indonesia menganut high context culture. Berbeda dengan budaya di Belanda yang langsung to the point ketika berbicara. 
Hal tersebut jika dikaitkan dengan low context culture dan high context culture menjawab bahwa orang Indonesia mengadopsi nilai high context culture yakni bahasa digunakan dengan konteks dan maksud tujuan tertentu. Sedangkan warga Belanda mengadopsi nilai low context culture sehingga hal itu terjadi. Namun demikian, seiring berjalannya waktu RJ melihat bahwa tidak semua orang Indonesia menganut cara berbicara berbelit-belit atau high context culture.

\section{Simpulan}

Kesimpulan pada penelitian ini adalah kesulitan dan kemudahan dalam melakukan adaptasi budaya berbeda bagi setiap warga negara. WNA yang berasal dari India lebih mudah melakukan proses adaptasi budaya di Indonesia dibandingkan dengan informan yang berasal dari New Zealand dan Belanda. Hal ini karena, ada sejumlah penerapan budaya yang hampir sama antar dua negara tersebut. Adopsi nilai budaya Indonesia lebih cenderung dilakukan oleh WNA yang berasal dari India sedangkan WNA yang berasal dari New Zealand dan Belanda hanya memahami, dan tidak mengadopsi nilai budaya Indonesia tersebut. Kemudian kesimpulan kedua adalah bahasa merupakan kendala terbesar yang dialami oleh WNA yang tinggal di Indonesia.

\section{Ucapan Terima Kasih}

Peneliti menyampaikan ucapan terima kasih kepada dosen pembimbing, kepada ketiga informan, kepada keluarga peneliti, teman-teman penulis, serta semua orang yang telah mendukung dan memberi semangat sehingga penelitian ini dapat terselesaikan dengan baik.

\section{Daftar Pustaka}

Astuti, M. T. (2017). Persepsi Budaya Pemandu Wisata Terhadap Wisatawan Korea Selatan (Studi Deskriptif Kualitatif Persepsi Budaya Pemandu Wisata Terhadap Wisatawan Korea Selatan di Jogjakarta). Doctoral dissertation, Universitas Mercu Buana Yogyakarta

Gumilang, G. S. (2016). Metode Penelitian Kualitatif Dalam Bidang Bimbingan dan Konseling. Jurnal Fokus Konseling, 2(2)

Peranginangin, B. B., \& Perbawaningsih, Y. (2017). Model Komunikasi Interpersonal Generasi Muda Suku Batak Karo di Yogyakarta Melalui Tradisi Ertutur. Jurnal ASPIKOM, 2(6), 425-436

Romli, K. (2017). Komunikasi massa. Gramedia Widiasarana.

Soemantri, N. P. (2019). Adaptasi Budaya Mahasiswa Asal Indonesia di Australia. Wacana: Jurnal Ilmiah Ilmu Komunikasi, 18(1), 46-56

Sudarmika, D. (2020). Memahami Perbedaan Komunikasi Antarbudaya di Lingkungan Tempat Kerja. Jurnal Oratio Directa (Prodi Ilmu Komunikasi), 2(2).

Tamengge, A., Mingkid, E., \& Tangkudung, J. P. M. (2019). Pola Komunikasi Antarbudaya Antara Suku Bajo dan Suku Minahasa di Desa Arakan. ACTA DIURNA KOMUNIKASI, 8(2)

Utami, L. S. S. (2016). Teori-Teori Adaptasi Antar Budaya. Jurnal Komunikasi, 7(2), 180-197. 